\title{
Technological properties of cow milk with the addition in their diet of silage prepared with bio-preservative "GreenGrass 3×3"
}

\author{
Sergey $V$. Karamaev $^{1 *}$, Natalya V. Soboleva ${ }^{2}$, Anna S. Karamaeva ${ }^{1}$, Nikolay A. Mironov ${ }^{1}$ \\ ${ }^{1}$ Samara State Agrarian University, 2, Uchebnaya Street, Ust-Kinelsky, Samara region, 446442, Russia \\ ${ }^{2}$ Orenburg State Agrarian University, 18, Chelyuskintsev str., Orenburg, 460795, Russia
}

\begin{abstract}
The completeness of the provision of the body of highly productive cows with the necessary set of nutrients depends on the set of feeds included in their diet, as well as on their quality. The purpose of the research is to study the effect of silage with the biological preservative "GreenGrass $3 \times 3$ " on the technological properties of milk from cows of Holstein and Ayrshire breeds. It is found that the morphological and biochemical composition of the blood in the animals of the experimental groups significantly improves approaching the optimal parameters. Feeding lactating cows with silage in feed mixture from lucerne prepared with bio-preservative increases the average daily milk yield by $20.5 \%$ in the Holstein breed and by $26.9 \%$ in the Ayrshire breed. The quality of milk is improved by the increase in the mass fat fraction by $0.10-0.13 \%$ respectively, the mass protein fraction - by $0.10-0.14 \%$, including casein by $0.14-0.19 \%$. In the general structure of milk proteins, the mass fraction of casein increases, while the mass fraction of whey proteins, on the contrary, decreased by $2.0-2.2 \%$. It is very important that the proportion of $\gamma$-caseins, which do not clot under the influence of rennet, decreased by $0.5-0.9 \%$ in the test samples. As a result, the duration of clotting by rennet decreased by $13.8-12.1 \%$ and the loss of dry matter with whey - by $1.3-2.1 \%$, the yield of casein clot increased by $5-4 \%$ and its density increased by $0,37-0.22 \mathrm{~g}$ $/ \mathrm{cm}^{2}$. All these aspects show the increase in the technological properties of milk in cows from the experimental groups.
\end{abstract}

\section{Introduction}

The experience of scientists and specialists in the field of dairy cattle breeding shows that a further increase in gross milk production is possible only when highly productive animals are used at modern dairy complexes. At the same time, it is well known that the realization of the genetic potential of cows by $60-65 \%$ depends on the quality of feed and the conditions of feeding. The main reason that moderates the breeding of highly productive animals is the problem of meeting the protein needs of their bodies. Due to the fact that bulky feed is the main source of nutrients for cattle, it is possible to increase the protein content in the diet only by increasing legumes in the fodder structure. Traditional fodder crops with a high content of vegetable protein are perennial grasses of the legume family: alfalfa, clover, vetch, Galega orientalis, etc. [1-7].

With all the advantages of legumes, they have a drawback - low sugar content in the dry matter composition, as a result of which the green mass poorly silages. In recent years, when harvesting silage, various preservatives have been widely used, which improve the quality of the finished feed and reduce the loss of nutrients during storage. At the same time, we are not talking about the increase in the number of lactic acid bacteria, which suppress the development of putrefactive and other undesirable microorganisms, but rather about the replacement of inactive epiphytic lactic acid bacteria with their highly effective strains that are a part of biological preservatives.

The main feature of this microflora is the ability to break down starch and dextrins of plant raw materials to lactic and acetic acids during the lactic acid fermentation. This contributes to the regulation of fermentation processes in the silage mass, prevents butyric fermentation, rotting, mold growth and creates additional fungistatic protection of the finished feed [813].

Due to the fact that the composition of biological preservatives includes strains of lactic acid, propionic acid, spore-forming bacteria, enzymes, complexes of amino acids, vitamins and microelements, it is very important to know what effect the feed prepared with their addition will have on the chemical composition and technological properties of milk, especially during cheese making, when microorganisms are also used [14, 15].

\section{Research purpose}

The purpose of the research is to study the effect of silage prepared using the biological preservative

\footnotetext{
* Corresponding author: karamaevsv@ mail.ru
} 
GreenGras $3 \times 3$ on milk productivity and technological properties of milk from Holstein and Ayrshire cows.

\section{Materials and methods}

The studies were carried o in dairy complex "Radna" in the Samara region. The objects of research were Holstein and Ayrshire cows after the second calving, 4 groups were formed of them with 24 animals in each group: I (control) - Holstein breed, II (control) - Ayrshire breed, which received silage from alfalfa without preservative in the feed mixture, III (experimental) Holstein breed, IV (experimental) - Ayrshire breed, which received silage prepared with bio-preservative "GreenGrass $3 \times 3$ ".

Blood and milk samples were taken from cows in the second month of lactation. The study of blood samples was carried out using the analyzer "VA-88", the chemical composition of milk was carried out using the analyzer "Laktan 1-4", the fractional composition of milk proteins were studied using the apparatus of capillary electrophoresis "Kapel 105M" in the Testing Research Laboratory of Samara State Agrarian University, technological properties of milk were studied in the Analytical laboratory of Orenburg State Agrarian University, according to generally accepted methods.

\section{Results and discussion}

The study of the quality of average samples of silage, taken two months after the trench laying, showed that the use of green mass of alfalfa, dried to a moisture content of $50-55 \%$, bio-preservative GreenGrass $3 \times 3$, which included strains of lactic acid, propionic acid and sporeforming bacteria, a complex of amino acids, enzymes, vitamins and microelements, had a positive effect on the nutritional value of the finished feed $[14,15]$.

In order to evaluate the effectiveness of the use of a new biological product for fodder conservation, it is necessary to know what effect it will have on the body and health of animals. Despite the fact that blood has the ability to maintain the relative constancy of its environment, it has the ability to change its composition under the influence of various paratypical factors. Therefore, one of the tasks was to determine how the feeding of silage will affect the morphobiochemical composition of the blood of cows (Table 1).

Table 1. Morphological and biochemical composition of blood

\begin{tabular}{|l|c|c|c|c|}
\hline \multirow{2}{*}{ Indicator } & \multicolumn{3}{|c|}{ Group } \\
\cline { 2 - 5 } & I & II & III & IV \\
\hline White blood cells, $10^{9} / 1$ & $7,39 \pm 0,38$ & $6,73 \pm 0,31$ & $7,12 \pm 0,29$ & $6,41 \pm 0,33$ \\
\hline Red blood cells, $10^{12} / 1$ & $5,41 \pm 0,27$ & $5,52 \pm 0,22$ & $5,84 \pm 0,31$ & $5,99 \pm 0,24$ \\
\hline hemoglobin, g/l & $100,12 \pm 3,76$ & $109,34 \pm 4,13$ & $121,56 \pm 4,69$ & $123,45 \pm 3,95$ \\
\hline Total protein, g/l & $78,56 \pm 1,73$ & $80,23 \pm 0,98$ & $81,79 \pm 1,38$ & $84,12 \pm 1,56$ \\
\hline Albumins, \% & $37,24 \pm 0,69$ & $39,86 \pm 0,73$ & $41,98 \pm 0,64$ & $43,94 \pm 0,59$ \\
\hline Globulins, $\%$ & $62,76 \pm 0,81$ & $60,14 \pm 0,64$ & $58,02 \pm 0,73$ & $56,06 \pm 0,67$ \\
\hline including $\alpha$ & $13,45 \pm 0,49$ & $11,92 \pm 0,53$ & $12,81 \pm 0,44$ & $10,39 \pm 0,38$ \\
\hline$\beta$ & $21,48 \pm 0,56$ & $17,94 \pm 0,67$ & $14,02 \pm 0,48$ & $12,11 \pm 0,54$ \\
\hline$\gamma$ & $27,83 \pm 0,62$ & $30,28 \pm 0,71$ & $31,19 \pm 0,69$ & $33,56 \pm 0,63$ \\
\hline ASAt, E/l & $15,51 \pm 0,69$ & $16,94 \pm 0,56$ & $16,82 \pm 0,71$ & $18,45 \pm 0,67$ \\
\hline ALAT, E/l & $11,26 \pm 0,51$ & $14,39 \pm 0,43$ & $13,94 \pm 0,58$ & $16,83 \pm 0,45$ \\
\hline
\end{tabular}

It was found that the change in all studied blood parameters occurred within the physiological norm. At the same time, the content of white blood cells decreased in Holstein cows by $0.27 \times 109 / \mathrm{L}(3.7 \%)$, Ayrshire - by $0.32 \times 109 / \mathrm{L}(4.8 \%)$. The content of red blood cells, on the contrary, increased by $0.43 \times 1012 / \mathrm{L}(7.9 \%)$ and $0.47 \times 1012 / \mathrm{L}(8.5 \%)$, respectively, and their saturation with hemoglobin increased by $21.44 \mathrm{~g} / \mathrm{L}$ ( $21.4 \%$; P $<0.01)$ and $14.11 \mathrm{~g} / \mathrm{L}(12.9 \%$; $\mathrm{P}<0.05)$.

Blood proteins play an important role in the life support of animal organism, participating in metabolic and other processes. They are included in enzymes and hormones. They also participate in the transport of nutrients and provide the formation of the body's immune status. In the structure of total blood protein in cows of the experimental groups, the proportion of albumin increased, and the proportion of globulins, respectively, decreased by $4.74-4.08 \%$ ( $\mathrm{P}<0.001$ ), mainly due to the $\alpha$ - and $\beta$-globulin fractions. In this case, the increase in the proportion of the fraction of $\gamma$ globulins, which provide a protective function in the body of animals against the adverse effects of the environment and pathogenic microflora, can be considered a positive phenomenon. The cows of the experimental groups had the increased content of $\gamma$ globulins, respectively, the increase was by $3.96 \%$ (P $<0.001)$ and $3.28 \%(\mathrm{P}<0.01)$. At the same time, the content of $\gamma$-globulins in the blood serum of Ayrshire was higher than that of Holsteins by $2.37 \%(\mathrm{P}<0.05)$.

The indicator of protein metabolism in the body of animals is the activity of transamination enzymes: aspartate aminotransferases (ASAT) and alanine aminotransferases (ALT), which are involved in protein biosynthesis, providing the transfer of the amino group from amino acids to keto acids, as well as the connection between protein, carbohydrate and lipid exchanges. The increase in the activity of ASAT in the experimental groups was established in cows of the Holstein breed by $1.31 \mathrm{U} / 1$ (8.5\%), in the Ayrshire breed - by $1.51 \mathrm{U} / 1$ $(8.9 \%)$, the activity of ALAT, respectively, by $2,68 \mathrm{U} / \mathrm{L}$ (23.8\%; P <0.01) and 2.44 U/L (17.0\%; P <0.001).

The improvement of the chemical composition of blood, which serves as an intermediary between all organs and systems of the body, ensuring their functional activity, had a positive effect on the chemical composition of milk from cows fed with silage with a biological preservative in theri diet (Table 2). 
Table 2. Chemical composition of milk

\begin{tabular}{|l|c|c|c|c|}
\hline \multirow{2}{*}{\multicolumn{1}{c|}{ Indicator }} & \multicolumn{4}{c|}{ Group } \\
\cline { 2 - 5 } & I & II & III & IV \\
\hline Number of cows, hea. & 24 & 24 & 24 & 24 \\
\hline Daily milk yield, kg & $25,9 \pm 0,78$ & $22,7 \pm 0,63$ & $31,2 \pm 0,81$ & $13,8 \pm 0,69$ \\
\hline Dry matter, \% & $12,06 \pm 0,39$ & $13,49 \pm 0,42$ & $12,37 \pm 0,34$ & $4,76 \pm 0,03$ \\
\hline FMF, \% & $3,68 \pm 0,03$ & $4,63 \pm 0,03$ & $3,78 \pm 0,2$ & $3,58 \pm 0,02$ \\
\hline PMF, \% & $3,02 \pm 0,02$ & $3,44 \pm 0,01$ & $3,12 \pm 0,01$ & $2,94 \pm 0,02$ \\
\hline Including casein, \% & $2,31 \pm 0,01$ & $2,75 \pm 0,01$ & $2,45 \pm 0,02$ & $0,64 \pm 0,01$ \\
\hline Whey protein, \% & $0,71 \pm 0,01$ & $0,69 \pm 0,01$ & $0,67 \pm 0,01$ & $4,69 \pm 0,05$ \\
\hline Milk sugar, \% & $4,63 \pm 0,05$ & $4,66 \pm 0,06$ & $4,68 \pm 0,04$ & $129,56 \pm 1,27$ \\
\hline Calcium, mg\% & $118,42 \pm 1,24$ & $121,83 \pm 1,36$ & $126,34 \pm 1,19$ & $104,37 \pm 0,98$ \\
\hline Phosphorous, mg\% & $96,73 \pm 1,12$ & $98,59 \pm 0,99$ & $101,63 \pm 0,94$ & $0,81 \pm 0,03$ \\
\hline Ash,\% $\%$ & $0,76 \pm 0,05$ & $0,79 \pm 0,04$ & \\
\hline
\end{tabular}

In terms of milk yield, the Holstein breed exceeded the Ayrshire breed in the control groups by $3.2 \mathrm{~kg}$ $(14.1 \%$; $\mathrm{P}<0.01)$, in the experimental ones - by $2.4 \mathrm{~kg}$ $(8.3 \% ; \mathrm{P}<0.05)$. The introduction of silage with biopreservative into the diet increased the daily milk yield of cows, respectively, by $5.3 \mathrm{~kg}(20.5 \%$; $\mathrm{P}<0.001)$ and $6.1 \mathrm{~kg}$ (26.9\%; P <0.001).

The Ayrshire breed surpassed the Holstein breed in milk quality. The dry matter content in the milk of cows fed with silage without preservative was by $1.43 \%$ higher, with a preservative - by $1.47 \%$. The main components of milk, which have a decisive influence on its technological properties, are fat mass fraction (FMF), protein mass fraction (PMF), calcium and phosphorus content. Feeding silage with a bio-preservative contributed to the increase in FMF in the milk of Holstein cows by $0.10 \%$ ( $\mathrm{P}<0.05)$, Ayrshire cows - by $0.13 \%$ ( $\mathrm{P}<0.01$ ), $\mathrm{PMF}$, respectively, by $0.10 \%$ ( $\mathrm{P}$ $<0.001)$ and $0.14 \%(\mathrm{P}<0.001)$, calcium content - by 7.92 $\mathrm{mg} \%$ (6.7\%; P <0.001); $7.73 \mathrm{mg} \%$ (6.3\%; P <0.001), phosphorus - $4.9 \mathrm{mg} \%(5.1 \% ; \mathrm{P}<0.001) ; 5.78 \mathrm{mg} \%$ (5.9\%; P <0.001).

Cheese suitability of milk determines the content of protein and basic protein fractions in it. Milk proteins are divided into two groups - casein, which is able to clot under the action of rennet, and whey proteins ( $\alpha$ lactoalbumin and $\beta$-lactoglobulin), which do not clot under the action of rennet. Therefore, the quality of the casein clot and the quality of the cheese produced from it depends on the content of proteins of these two groups in milk. It is known that for the production of high-quality hard cheese it is necessary that the casein content in milk is not less than $2.70 \%$. The introduction of silage with a bio-preservative into the diet provided the increase in the proportion of casein in the milk proteins of Holstein cows by $0.14 \%$ ( $\mathrm{P}<0.001)$, Ayrshire cows - by $0.19 \%$ (P $<0.001)$. Even in this case, the milk from Holstein cows did not meet the minimum requirements for cheese making.

The studies showed that, along with the mass fraction of casein in the composition of milk proteins, the structure of casein had a significant effect on cheese suitability. Casein consists of four main fractions: $\alpha$ - and $\beta$-caseins, which are able to precipitate under the influence of calcium ions, $\kappa$-caseins act as a protective colloid, which prevents the clotting of proteins in fresh milk, and $\gamma$-caseins, which do not clot under the influence of rennet (Table 3).

Table 3. Milk protein structure

\begin{tabular}{|c|c|c|c|c|}
\hline \multirow{2}{*}{ Indicator } & \multicolumn{3}{|c|}{ Group } \\
\cline { 2 - 5 } & I & II & III & IV \\
\hline $\begin{array}{l}\text { Mass fraction of casein in the } \\
\text { composition of proteins, \% }\end{array}$ & $76,5 \pm 0,13$ & $79,9 \pm 0,09$ & $78,5 \pm 0,11$ & $82,1 \pm 0,12$ \\
\hline $\begin{array}{c}\text { Including } \\
\alpha \text {-caseins }\end{array}$ & $34,9 \pm 0,05$ & $37,1 \pm 0,04$ & $36,1 \pm 0,03$ & $39,0 \pm 0,04$ \\
\hline$\beta$ - caseins & $27,6 \pm 0,06$ & $28,5 \pm 0,07$ & $28,7 \pm 0,05$ & $29,1 \pm 0,03$ \\
\hline$\kappa$ - caseins & $6,9 \pm 0,03$ & $7,8 \pm 0,02$ & $7,1 \pm 0,01$ & $8,4 \pm 0,02$ \\
\hline$\gamma$ - caseins & $7,1 \pm 0,03$ & $6,5 \pm 0,04$ & $6,6 \pm 0,03$ & $5,6 \pm 0,03$ \\
\hline Mass fraction of whey proteins \% & $23,5 \pm 0,10$ & $20,1 \pm 0,08$ & $21,5 \pm 0,11$ & $17,9 \pm 0,09$ \\
\hline
\end{tabular}

Silage with a bio-preservative, getting into the body of cows, during the digestion and assimilation of nutrients had a positive effect on the process of lactogenesis, as a result of which the mass fraction of casein in the composition of milk proteins increased in the Holstein breed by $2.0 \%$ ( $\mathrm{P}<0.001)$, in the Ayrshire breed - by $2.2 \%(\mathrm{P}<0.001)$. This is very important, since casein is a pure milk protein. It is not contained in feed, but it is synthesized directly in the cells of the secretory epithelium of the udder alveoli.
In addition, it is necessary to note that certain changes in the structure of casein were found in the milk samples of the experimental groups. In the Holstein breed, the proportion of the $\alpha$-casein fraction increased by $1.2 \%(\mathrm{P}<0.001)$, the Ayrshire breed - by $1.9 \%$ (P $<0.001)$, the proportion of $\beta$-caseins, respectively, by $1.1 \%(\mathrm{P}<0.001)$; $0.6 \%(\mathrm{P}<0.001)$, $\kappa$-caseins - by $0.2 \%$ $(\mathrm{P}<0.001)$ and $0.6 \%(\mathrm{P}<0.001)$. At the same time, the proportion of $\gamma$-caseins in milk proteins decreased by $0.5 \%(\mathrm{P}<0.001)$ and $0.9 \%(\mathrm{P}<0.001)$. 
Thus, the decrease in the mass fraction of whey proteins, for breeds by $2.0 \%(\mathrm{P}<0.001)$ and $2.2 \%(\mathrm{P}$ $<0.001)$ respectively, as well as the decrease in the fraction of $\gamma$-casein, significantly improved the technological properties and cheese suitability of milk of cows fed in the diet with silage with bio-preservative (Table 4).

Table 4. Technological properties of milk

\begin{tabular}{|l|c|c|c|c|}
\hline \multirow{2}{*}{ Indicator } & \multicolumn{4}{|c|}{ Group } \\
\cline { 2 - 5 } & I & II & III & IV \\
\hline $\begin{array}{l}\text { Duration of clotting by } \\
\text { rennet, min }\end{array}$ & $42,8 \pm 0,63$ & $34,6 \pm 0,54$ & $36,9 \pm 0,57$ & $30,4 \pm 0,66$ \\
\hline Including clotting stage & $33,9 \pm 0,47$ & $27,4 \pm 0,39$ & $28,6 \pm 0,42$ & $23,6 \pm 0,34$ \\
\hline Gelation phase & $8,9 \pm 0,29$ & $7,2 \pm 0,26$ & $8,3 \pm 0,21$ & $6,8 \pm 0,23$ \\
\hline $\begin{array}{l}\text { Duration of clot } \\
\text { processing, min }\end{array}$ & $58,7 \pm 1,42$ & $50,4 \pm 1,27$ & $53,2 \pm 1,19$ & $44,3 \pm 0,98$ \\
\hline $\begin{array}{l}\text { Waste of dry matter } \\
\text { into whey,\% }\end{array}$ & $55,6 \pm 0,48$ & $52,9 \pm 0,56$ & $54,3 \pm 0,61$ & $50,8 \pm 0,52$ \\
\hline $\begin{array}{l}\text { Fraction ratio clot: } \\
\text { whey, } \%\end{array}$ & $25: 75$ & $38: 62$ & $30: 70$ & $42: 58$ \\
\hline
\end{tabular}

The chemical composition of the milk of cows of the studied breeds, especially its protein component, had a decisive influence on the clotting process and the formation of a casein clot. In this regard, in the control groups, the duration of milk clotting of the Holstein breed was longer than that of the Ayrshire breed by 8.2 minutes (23.7\%; $\mathrm{P}<0.001)$, and in the experimental groups, respectively, by 6.5 minutes $(21.4 \%$; $\mathrm{P}<0.001)$. Feeding cows with silage with a bio-preservative helped to reduce the clotting time of Holstein milk by 5.9 minutes (13.8\%; P <0.001), Ayrshire - by 4.2 minutes $(12.1 \% ; \mathrm{P}<0.001)$.

At the same time it is necessary to note that the reduction in the time of milk clotting occurred mainly due to a reduction in the clotting phase (by 15.6-13.9\%), with a slight change in the gelation phase (by 6.7-5.6\%).

The duration of its processing and the intensity of the separation of whey depend on the quality of the formed clot. It was found that in the experimental groups the duration of processing with lyres and stirring the cheese mass was reduced by 5.5-6.1 minutes (9.4-12.1\%; $\mathrm{P}$ $<0.01-0.001)$. Due to the denser adhesion of casein micelles, with the formation of a casein-calcium conglomerate, the waste of dry matter into whey decreased in the samples of group III by $1.3 \%$, in group IV - by $2.1 \%$. As a result, the yield of casein clot in the milk of Holstein cows increased by 5\%, Ayrshire cows by $4 \%$.

Ultimately, the use of silage with bio-preservative in the feeding of cows allowed increasing the quality of milk, optimizing the structure of casein fractions in milk protein and significantly improving the technological properties of milk in cows from the experimental groups. At the same time, due to biological characteristics, the Ayrshire breed surpassed its peers of the Holstein breed in terms of the yield of casein clot by $12 \%$. In addition, the casein clot from the Ayrshire breed milk had higher quality indicators, which was very important in cheese making (Table 5).

Table 5. Characteristics of a casein clot

\begin{tabular}{|l|c|c|c|c|}
\hline \multirow{2}{*}{\multicolumn{1}{|c|}{ Indicator }} & \multicolumn{3}{c|}{ Group } \\
\cline { 2 - 5 } & I & II & III & IV \\
\hline $\begin{array}{l}\text { Casein clot condition, \% } \\
\text { dense }\end{array}$ & - & 54,2 & 20,8 & 70,8 \\
\hline loose & 33,3 & 33,3 & 41,7 & 20,8 \\
\hline flabby & 54,2 & 12,5 & 33,3 & 8,4 \\
\hline unclotted & 12,5 & - & 4,2 & - \\
\hline Density of casein clot, g/cm ${ }^{2}$ & $1,73 \pm 0,06$ & $2,86 \pm 0,05$ & $2,10 \pm 0,04$ & $3,08 \pm 0,03$ \\
\hline Moisture holding capacity of clot, \% & $45,6 \pm 0,31$ & $63,9 \pm 0,38$ & $51,2 \pm 0,26$ & $66,7 \pm 0,34$ \\
\hline
\end{tabular}

As a result of research, it was found that the best quality casein clots were obtained from the milk of Ayrshire cows, regardless of the method of making silage that was fed. In accordance with the requirements of technical conditions for high-quality cheese making, the milk which forms a dense casein clot after exposure to rennet is only suitable. When feeding silage without preservative, in the group of the Holstein breed, there were no animals with such quality of milk; in the group of the Ayrshire breed, 54.2\% of cows with such type of milk were found. The inclusion of silage with biopreservative in the diet improved the quality of the casein clot and increased the proportion of Holstein cows with a dense clot in the group by $20.8 \%$, Ayrshire cows by $16.6 \%$. At the same time, in the Ayrshire breed, the proportion of cows with a dense casein clot was more than in the Holstein breed by $50.0 \%$.

The density of the casein clot in the cows of the experimental groups was higher than in the control ones, respectively for breeds by $0.37 \mathrm{~g} / \mathrm{cm}^{2}$ (21.4\%; P $<0.001)$ and $0.22 \mathrm{~g} / \mathrm{cm}^{2}(7.7 \% ; \mathrm{P}<0.001)$. Despite this, according to the technical conditions, which provided the density of casein clot for cheese making in the range of 2.7-3.5 $\mathrm{g} / \mathrm{cm}^{2}$, the milk of Holstein cows was found unsuitable for the production of hard cheese.

The high water-holding capacity of the clot ensures the decrease in the loss of dry matter and its constituent 
components during syneresis of processing. It also contributes to the formation of such important technological properties as density and elasticity.

\section{Conclusion}

The results of the research showed that with the addition of silage prepared with the bio-preservative GreenGras $3 \times 3$ in the diet of lactating cows, metabolic processes in the body of animals improved, as evidenced by the optimal indicators of the morpho-biochemical composition of the blood. In the milk of cows of the experimental groups, the dry matter content increased, including the mass fat fraction by $0.10-0.13 \%$, the mass protein fraction - by $0.10-0.14 \%$.

The mass fraction of casein in the total composition of milk proteins increased. While the mass fraction of whey proteins, on the contrary, decreased by $2.0-2.2 \%$. As a result, the duration of clotting by rennet decreased by $13.8-12.1 \%$, the loss of dry matter with whey - by $1.3-2.1 \%$, the yield of casein clot increased by $5-4 \%$, and its density increased - by $0.37-0.22 \mathrm{~g} / \mathrm{cm}^{2}$. All this shows to the increase in the technological properties of milk in cows from the experimental groups.

\section{References}

1. S. D. Batanov, O. S. Starostina, I. A. Baranova, Genetic parameters of productivity and exterior traits of dairy cattle, IOP Conference Series: Earth and Environmental Science, 548(3), 032023 (2020). DOI: $10.1088 / 1755-1315 / 548 / 3 / 032023$

2. S. D. Batanov, O. S. Starostina, Blood Parameters as Indicators of Physiological Condition of Animals, TieraerztlicheUmschau, 1-2, 14-19 (2018)

3. A. T. Varakin, V. V. Salomatin, Dairy productivity of cows when feeding alfalfa silage harvested with a new preservative, Bulletin of the Lower Volga agrouniversity complex: science and higher professional education, 2, 90-94 (2012)

4. I. M. Dunin, S. E. Tyapugin, R. K. Mescherov et al., Pedigree resources of the Holstein cattle breed: state and results of use, Zootekhniya, 5, 8-11 (2019)

5. L. P. Zaripova, F. S. Gibadullina, Sh. K. Shakirov et al., Forage of the Republic of Tatarstan: composition, nutritional value and use (Foliant, Kazan, 2010)
6. V.P. Klimenko, V.M. Kosolapov, A.V. Logutov, The use of biological products for the preparation of silage and haylage from leguminous herbs, Animal husbandry, 1, 12-15 (2017)

7. Yu.A. Pobednov, I.V. Kuchin, V.V. Soldatov, Comparative efficiency of silage and silage of wilted cereal grasses with lactic acid bacteria preparations, Kormoproizvodstvo, 3, 36-40 (2016)

8. A. V. Andreeva, O. N. Nikolaeva, E. R. Ismagilova, V. R. Tuktarov, R. G. Fazlayev, A. I. Ivanov, O. M. Altynbekov, G. M. Sultangazin, I. M. Urmanov, A. Z. Khakimova, Effect of Probiotic Preparations on the Intestinal Microbiome, Journal of Engineering and Applied Sciences, 13, 6467-6472 (2018)

9. W. Brade, The stature of Holstein cows - a critical review, Tieraerztliche Umschau, 73(3), 74-84 (2017)

10. L. Calamari, F. Petrera, F. Abeni, G. Bertin, Metabolic and hematological profiles in heat stressed lactating dairy cows fed diets supplemented with different selenium sources and doses, Livestock Science, 142(1), 128-137 (2011)

11. N. Gubaidullin, H. Tagirov, I. Mironova, Y. Lysov, F. Gafarov, L. Zubairova, R. Iskhakov, A. Nigmatyanov, A. Bagautdinov, E. Pozdnyakova, The efficiency of silage use conserved by the pure culture of propionibacteria in black-and-white cattle feeding, Bulgarian Journal of Agricultural Science, 25 (Suppl. 2), 74-79 (2019)

12. L. Ir. Kung, A review on silage additives and enzymes (Department of Animal and Food Sciences, University of Delaware Newark, DE 19717-1303, 2010)

13. H. H. Tagirov, F. F. Vagapov, N. V. Gizatova, Quality of tanning raw material when feeding to probiotic gobies, News of Science and Education, 1(3), 27-29 (2018)

14. S. V. Karamaev, A. S. Karamaeva, N. V. Soboleva, L. N. Bakaeva, Milk productivity of cows when silage with biological preservatives is include in the diet, IOP Conference Series: Earth and Enviromental science, 403, 012081 (2019)

15. S. V. Karamaev, A. S. Karamaeva, Kh. Z. Valitov, N. V. Soboleva, L. N. Bakaeva, Milk productivity and milk quality when feeding cows with silostan containing haulage, BIO Web of Conferences, 17(3), 00007 (2020) 